\title{
BUSINESS MANAGEMENT VIA AN ECONOMETRIC MODEL ON FIDITOUR STOCK PRICE - A CASE IN TOURISM INDUSTRY IN VIETNAM
}

\author{
NGUYEN DUY MAU ${ }^{1}$, DINH TRAN NGOC HUY ${ }^{2} \&$ LE NGOC NUONG ${ }^{3}$ \\ ${ }^{1}$ DaLat University, Vietnam
}

${ }^{2}$ Banking University, HCM City, Vietnam - GSIM, International University of Japan, Niigata, Japan

${ }^{3}$ TNU-University of Economics and Business Administration (TUEBA), Thai Nguyen, Vietnam

\begin{abstract}
Fluctuation of stock price in commercial banks in developing countries such as Vietnam will reflect the business health of bank system and the whole economy. Good business management requires us to consider the impacts of multi macro factors on stock price, and it contributes to promoting business plan and economic policies for economic growth and stabilizing macroeconomic factors. By data collection method through statistics, analysis, synthesis, comparison, quantitative analysis to generate qualitative comments and discussion; using econometric method to perform regression equation and evaluate quantitative results, the article analyzed and evaluated the impacts of six (6) macroeconomic factors on stock price of a joint stock commercial bank, Vietcombank (VCB) in Vietnam in the period of 2014-2019, both positive and negative sides. The results of quantitative research, in a seven factor model, show that the increase in GDP growth and lending rate and risk free rate has a significant effect on increasing VCB stock price with the highest impact coefficient, the second is decreasing the exchange rate. This research finding and recommended policy also can be used as reference in policy for commercial bank system in many developing countries.

KEYWORDS: Bank Stock Price; GDP Growth; Inflationary; Risk Free Rate; Market Interest Rate JEL: M21, N1
\end{abstract}

Received: Jun 08, 2020; Accepted: Jun 28, 2020; Published: Sep 03, 2020; Paper Id.: IJMPERDJUN20201032

\section{INTRODUCTION}

The development strategy of FIDITOUR is to focus on quality, high quality, and attentive care with products tailored to customers' needs in order to provide guests with satisfied vacation trips as the foundation. branding a sustainable FIDITOUR in the hearts of tourists.

During the past years, FIDITOUR has always improved and diversified its types to meet the needs of customers with products: popular for middle-class customers; Relaxation for guests coming back to their sights for a second time with a more comfortable, higher quality program; Hi-class for high-end guests; Package Tou and partial tour; Tour ships at home and abroad; Types of MICE; Study abroad and study abroad. Tour quality has been standardized according to the version every year, preventive Quality Control testing before, during and after tour, standardize service style, manage tour quality.

Tourism system in Vietnam in recent years plays a key role in helping the whole economy. In the context that GDP growth in Vietnam has been increasing during 2014-2019 and CPI goes down and up and Vietnam stock market has been growing much, it is necessary to evaluate impacts of seven (7) internal and external macro 
economic factors on tourism company performance, esp. Fiditour (FDT) stock price. From these analytical results, we could suggest bank and government policies to encourage and stabilize the growth of bank system and stock market in developing countries such as Vietnam.

Looking at the below chart, we find out that FDT stock price moves in the same trend with VN Index and GDP growth, although it fluctuates in a smaller range.

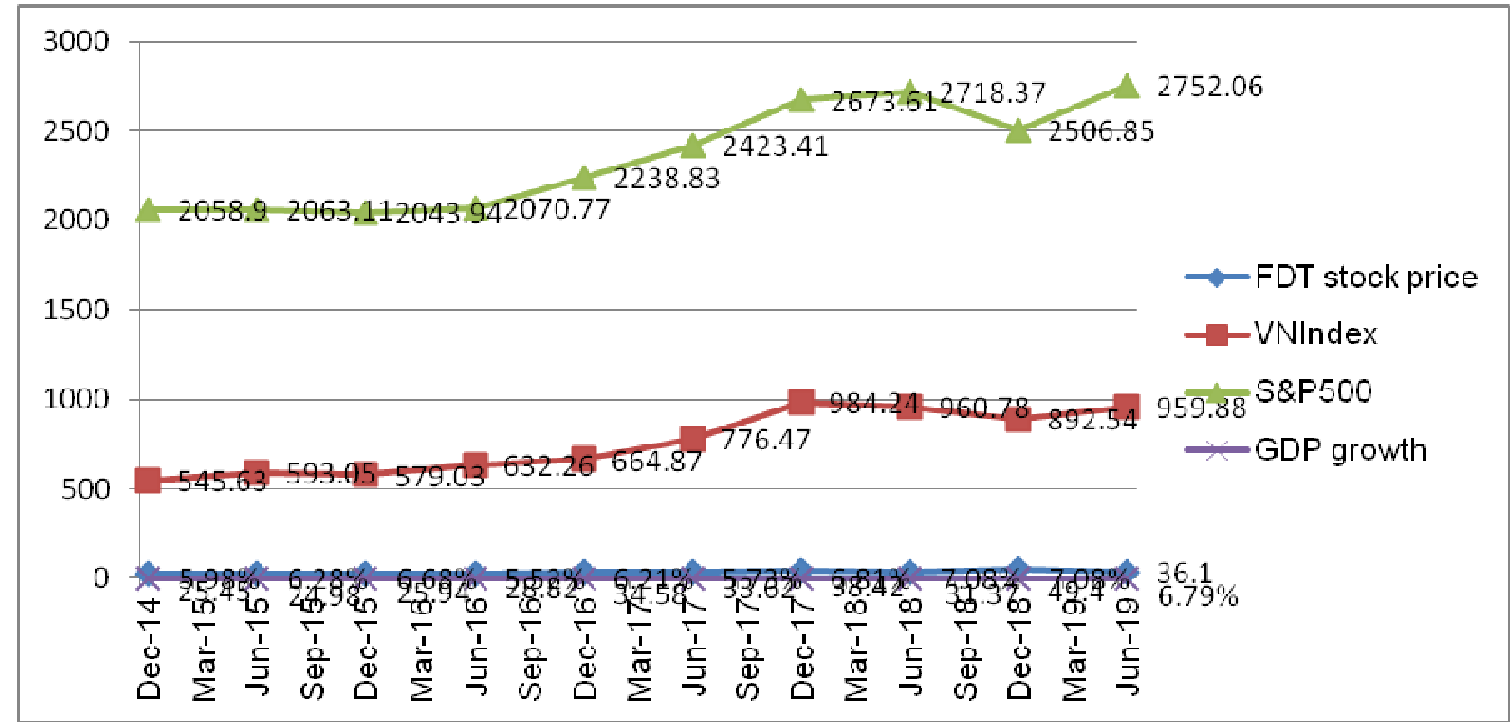

Figure 1

This study will calculate and figure out the impacts of seven (7) macro economic factors such as inflation, GDP growth, market interest rate, risk free rate, VN Index, S\&P500 and exchange rate on FDT stock price.

The paper is organized as follows: after the introduction it is the research issues, literature review and methodology. Next, section 3 will cover methodology and data and section 4 presents main research findings/results. Section 5 gives us some discussion and conclusion and policy suggestion will be in the section 6 .

\section{BODY OF MANUSCRIPT}

\section{Research Issues}

The scope of this study will cover:

- Issue 1: What are the correlation and relationship among many economic factors: FDT stock price, interest rate, exchange rate, inflation, VN Index, S\&P 500 and GDP growth?

- Issue 2: What are the impacts of above 7 macro economic factors on FDT stock price?

- Issue 3: Based on above discussion, we recommend some solutions regarding to tourism management in incoming period.

This paper also tests two (2) below hypotheses:

- Hypothesis 1: An increase in lending rate will make FDT stock price declines.

- Hypothesis 2: An increase in inflation can increase pressure in FDT stock price. 


\section{Literature Review}

Lina (2012) indicated that both the change of inflation rate and the growth rate of money supply (M2) are positive but insignificant to the banking industry stock return, the exchange rate is positive and significant to banking industry stock return and interest rate is negative and significant to banking industry stock return. Next, Sadia and Noreen (2012) found out exchange rate, and Short term Interest Rate have significant impact on Banking index. Macroeconomic variables like Money Supply, Exchange Rate, Industrial Production, and Short Term Interest Rate affects the banking index negatively where as Oil prices has a positive impact on Banking index.

Manisha and Shikha (2014) stated that Exchange rate, Inflation, GDP growth rate affect banking index positively whereas Gold prices have negative impact on BSE Bankex but none of them have significant impact on Bankex. Then, Winhua and Meiling (2014) confirmed that macroeconomic do have a substantial influence to the earning power of commercial banks.

Krishna (2015) investigated the nature of the causal relationships between stock prices and the key macro economic variables in BRIC countries. The empirical evidence shows that long-run and short-run relationship exists between macro economic variables and stock prices, but this relationship was not consistent for all of the BRIC countries. And Kulathunga (2015) suggested that all macroeconomic factors influence the stock market development. More precisely, volatile inflation rate and exchange rate together with higher deposit rate have curtailed the stock market development in Sri Lanka. Moreover, positive optimism created by the economic growth and the stock market performance during the previous periods tend to enhance stock market performance. Moreover, Duy (2015) mentioned through the evolution of interest rates and the VNI could see that the relationship between these two variables in the period 2005-2014 is the opposite. This relationship is shown in specific periods of the year the stock market proved quite sensitive to interest rates. When interest rates are low or high but the bearish stock market rally, and vice versa when the high interest rates the stock market decline.

Last but not least, Quy and Loi (2016) found that 3 economic factors (inflation rate, GDP growth rate, and exchange rate) impact significantly on real estate stock prices; but the relationship between 10-year Government bond yield and trading volume, and real estate stock prices was not found. Ahmad and Ramzan (2016) stated the macroeconomic factors have important concerns with stocks traded in the stock market and these factors make investors to choose the stock because investors are interested to know about the factors affecting the working of stock to manage their portfolios. Abrupt variations and unusual movements of macroeconomic variables cause the stock returns to fluctuate due to uncertainty of future gains.

Until now, many researchers have been done in this field, however, they just stop at analyzing internal macroeconomic factors on stock price.

Within the scope of this paper, we measure impacts of both internal and external macro factors on FDT stock price and suggest policies for bank system, Vietnam government, Ministry of Finance, State Bank and relevant government bodies. We also analyze data throughout time series from 2014-2019. 


\section{METHODOLOGY AND DATA}

This research paper establishes correlation among macro economic factors by using an econometric model to analyze impacts of seven (7) macro economic factors in Vietnam such as: GDP growth, inflation, interest rate, exchange rate, on FDT stock price.

In this research, analytical method is used with data from the economy such as inflation in Vietnam and market interest rate, GDP growth rate, exchange rate (USD/VND). Data are included from 2014 -2019 with semi-annual data (10 observations in total). Data is estimated based on exchange rate and lending interest rates of commercial banks such as: Vietcombank, BIDV, Agribank, Vietinbank (average calculation). S\&P 500 index data is from USA Stock exchange, data source (inflation, GDP) is from Bureau of Statistics. Beside, econometric method is used with the software Eview. It will give us results to suggest policies for businesses and authorities.

We build a regression model with Eview software to measure impacts of factors. FDT stock price is a function with 6 variables as follows:

$Y(F D T$ stock price $)=f(x 1, x 2, x 3, x 4, x 5, x 6, x 7)=a x 1+b x 2+c x 3+d x 4+e x 5+f \times 6+k$

With: $x 1$ : GDP growth rate $(\mathrm{g}), \mathrm{x} 2$ : inflation, $\mathrm{x} 3$ : VN Index, $\mathrm{x} 4$ : lending rate, x5: risk free rate (Rf), x6: USD/VND rate

Beside, this paper also uses analytical and general data analysis method to measure and generate comments on the results, then suggest policies based on these analyses.

\section{MAIN RESULTS}

\section{General Data Analysis}

First of all, the below chart 1 shows us that Y has a positive correlation with GDP growth:

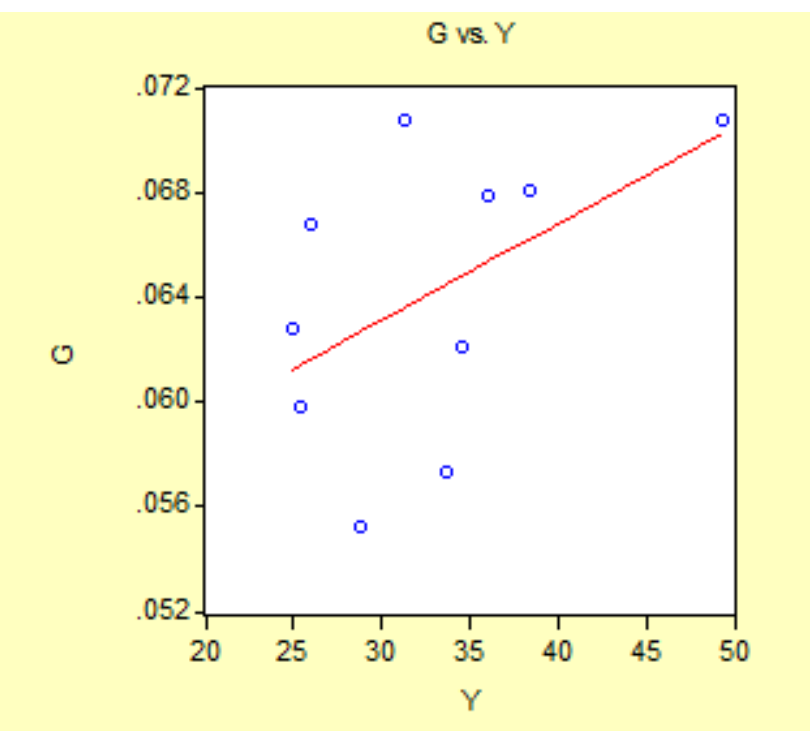

Chart 1: FDT Stock Price (Y) vs. GDP Growth in Vietnam (G). 
Next we find out that, based on the below scatter chart, Y (VCB stock price) has positive correlation with inflation (CPI).

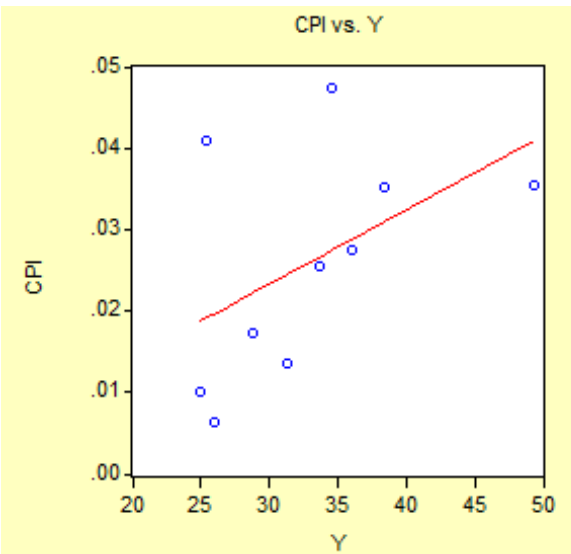

Chart 2: FDT Stock Price (Y) vs. Inflation (CPI).

Looking at the below chart 3, we also recognize that FDT stock price (Y) and VN Index have positive correlationship.

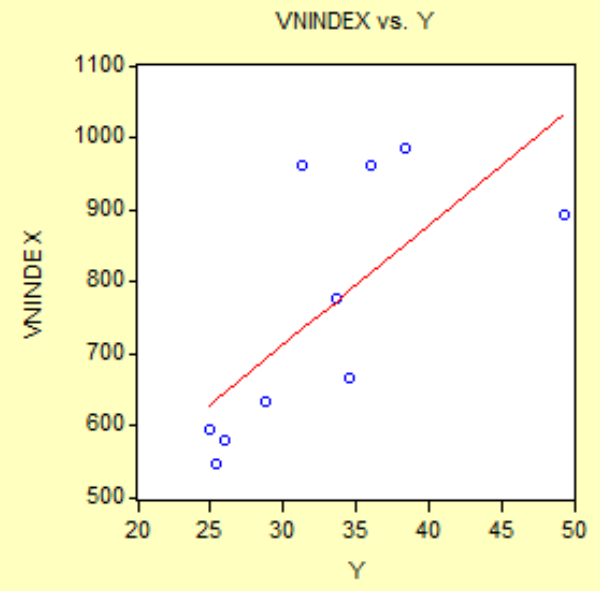

Chart 3: Y vs. VN Index.

We see that, FDT stock price $(\mathrm{Y})$ and lending rate have negative correlation:

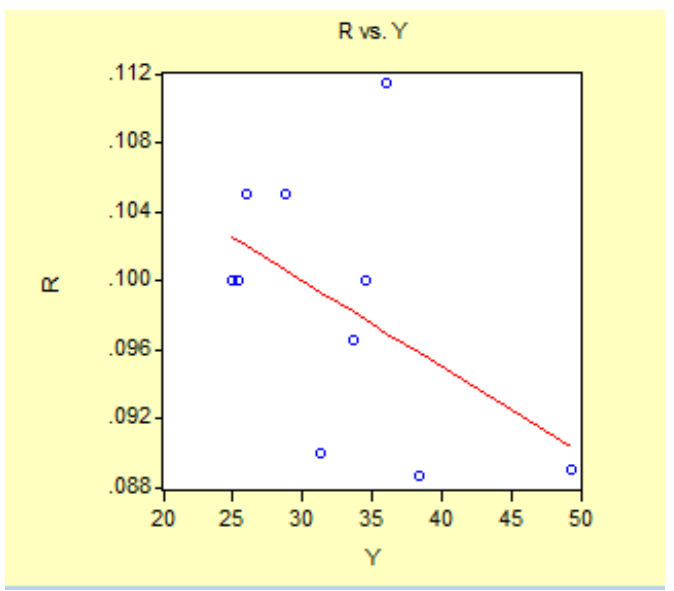

Chart 4: Y vs. Lending Rate (r). 
In addition to, the below scatter graph shows us that FDT stock price (Y) and risk free rate (Rf) also have negative correlation.

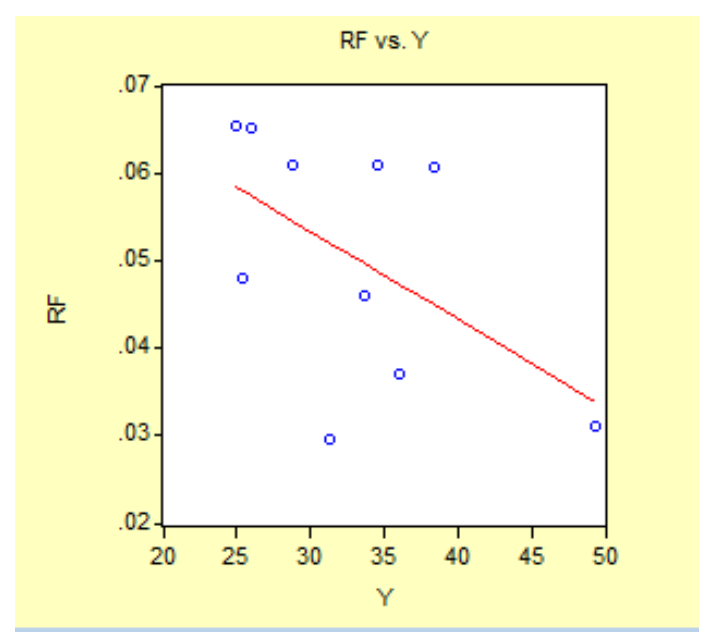

Chart 5: Y vs. Risk Free Rate (Rf).

The below chart 6 shows us that $\mathrm{Y}$ and USD/VND rate have a positive correlation.

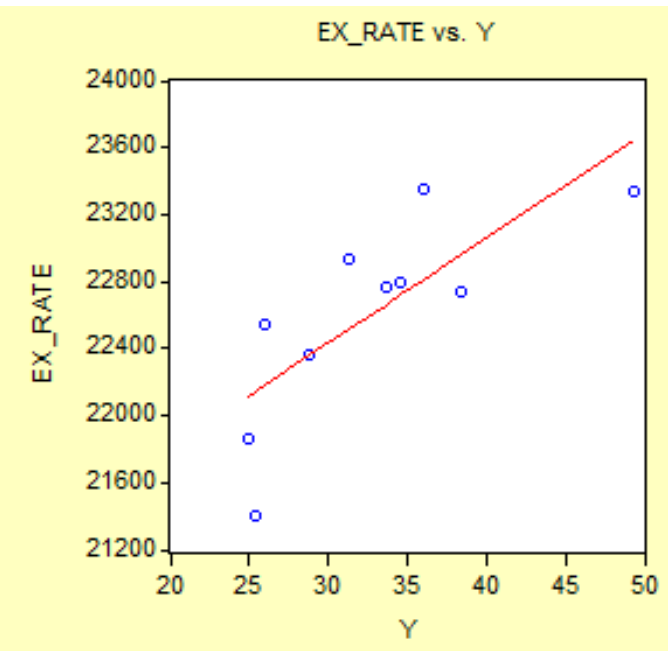

Chart 6: Y vs. Exchange Rate (Ex_rate).

On the other hand, we could see statistical results with Eview in the below table with 6 variables:

Table 1: Statistics for Macro Economic Factors.

\begin{tabular}{|l|c|c|c|c|c|c|c|}
\hline & $\begin{array}{c}\text { FDT stock } \\
\text { price64.13 }\end{array}$ & $\begin{array}{c}\text { GDP } \\
\text { growth }\end{array}$ & $\begin{array}{c}\text { Inflation } \\
(\mathbf{C P I})\end{array}$ & $\begin{array}{c}\text { VN } \\
\text { Index }\end{array}$ & $\begin{array}{c}\text { Lending } \\
\text { rate }\end{array}$ & $\begin{array}{c}\text { Risk free } \\
\text { rate }\end{array}$ & $\begin{array}{c}\text { USD/VND } \\
\text { rate }\end{array}$ \\
\hline Mean & 32.87 & 0.06416 & 0.02588 & 758.875 & 0.09856 & 0.050485 & 22611.7 \\
\hline Median & 32.49 & 0.0648 & 0.0264 & 720.67 & 0.1 & 0.05435 & 22757.5 \\
\hline Maximum & 49.4 & 0.0708 & 0.0474 & 984.24 & 0.1115 & 0.06535 & 23350 \\
\hline Minimum & 24.9 & 0.0552 & 0.0063 & 545.63 & 0.0886 & 0.0297 & 21405 \\
\hline Standard dev. & 7.468 & 0.005549 & 0.013884 & 176.4835 & 0.007636 & 0.014066 & 610.2313 \\
\hline
\end{tabular}

Looking at the above table, we recognize that standard deviation of exchange rate and VN Index are the highest values. Whereas standard deviation of GDP growth and lending rate are the lowest values.

If we want to see correlation matrix of these 8 macro variables, Eview generate the below result in table 2: 
Table 2: Correlation Matrix for Seven (7) Macro-Economic Variables (GDP Growth, Inflation in VN, Market Interest Rate, Risk Free Rate, Exchange Rate and FDT Stock Price)

\begin{tabular}{c|c|r|r|r|r|r|r|r|}
\hline \multicolumn{9}{|c|}{ Correlation Matrix } \\
\hline & Y & G & CPI & VNINDEX & \multicolumn{1}{c|}{ R } & RF & EX RATE & SP500 \\
\hline Y & 1.000000 & 0.499137 & 0.486796 & 0.700464 & -0.488121 & -0.535988 & 0.768233 & 0.639421 \\
\hline G & 0.499137 & 1.000000 & -0.050535 & 0.653067 & -0.390583 & -0.474076 & 0.564582 & 0.634468 \\
\hline CPI & 0.486796 & -0.050535 & 1.000000 & 0.146050 & -0.220576 & -0.158705 & 0.082310 & 0.183559 \\
\hline VNINDEX & 0.700464 & 0.653067 & 0.146050 & 1.000000 & -0.440372 & -0.634696 & 0.777514 & 0.983824 \\
\hline R & -0.488121 & -0.390583 & -0.220576 & -0.440372 & 1.000000 & 0.302601 & -0.154750 & -0.374293 \\
\hline RF & -0.535988 & -0.474076 & -0.158705 & -0.634696 & 0.302601 & 1.000000 & -0.521420 & -0.677534 \\
\hline EX_RATE & 0.768233 & 0.564582 & 0.082310 & 0.777514 & -0.154750 & -0.521420 & 1.000000 & 0.755250 \\
\hline SP500 & 0.639421 & 0.634468 & 0.183559 & 0.983824 & -0.374293 & -0.677534 & 0.755250 & 1.000000 \\
\hline
\end{tabular}

The above table 2 shows us that correlation among 7 macro variables. An increase in exchange rate and decrease in lending rate might lead to an increase in FDT stock price. It also indicates that correlation between FDT stock price (Y) in Viet Nam and VN Index in Viet Nam and S\&P 500 in the US (0.7 and 0.63) is higher than that between Y and lending rate (-0.4) or between Y and CPI (0.48).

The below table 3 shows us that covariance matrix among 7 macro economic variables. FDT stock price (Y) has a negative correlation with risk free rate and lending rate but has a positive correlation with exchange rate (EX_Rate), CPI and GDP growth.

Hence, an increase in GDP may lead to an increase in FDT stock price.

Table 3: Covariance Matrix for 7 Macro Economic Variables

\begin{tabular}{c|c|c|c|c|c|c|c|c|}
\hline \multicolumn{9}{|c|}{ Covariance Matrix } \\
\hline & Y & G & CPI & VNINDEX & R & \multicolumn{1}{c}{ RF } & EX RATE & SP500 \\
\hline Y & 50.19488 & 0.018615 & 0.045425 & 830.8848 & -0.025051 & -0.050673 & 3150.927 & 1267.532 \\
\hline G & 0.018615 & $2.77 \mathrm{E}-05$ & $-3.50 \mathrm{E}-06$ & 0.575578 & $-1.49 \mathrm{E}-05$ & $-3.33 \mathrm{E}-05$ & 1.720538 & 0.934488 \\
\hline CPI & 0.045425 & $-3.50 \mathrm{E}-06$ & 0.000173 & 0.322068 & $-2.10 \mathrm{E}-05$ & $-2.79 \mathrm{E}-05$ & 0.627614 & 0.676458 \\
\hline VNINDEX & 830.8848 & 0.575578 & 0.322068 & 28031.78 & -0.534085 & -1.418033 & 75361.46 & 46087.69 \\
\hline R & -0.025051 & $-1.49 \mathrm{E}-05$ & $-2.10 \mathrm{E}-05$ & -0.534085 & $5.25 \mathrm{E}-05$ & $2.93 \mathrm{E}-05$ & -0.648952 & -0.758612 \\
\hline RF & -0.050673 & $-3.33 \mathrm{E}-05$ & $-2.79 \mathrm{E}-05$ & -1.418033 & $2.93 \mathrm{E}-05$ & 0.000178 & -4.028085 & -2.529699 \\
\hline EX_RATE & 3150.927 & 1.720538 & 0.627614 & 75361.46 & -0.648952 & -4.028085 & 335144.0 & 122334.5 \\
\hline SP500 & 1267.532 & 0.934488 & 0.676458 & 46087.69 & -0.758612 & -2.529699 & 122334.5 & 78286.05 \\
\hline
\end{tabular}

\section{Regression Model and Main Findings}

In this section, we will find out the relationship between eight macro economic factors and public debt.

Scenario 1: Regression model with single variable: analyzing impact of GDP growth $(\mathrm{G})$ on MAS stock price (Y)

Note: C: constant

Using Eview gives us the below results: 


\begin{tabular}{|c|c|c|c|c|}
\hline \multicolumn{5}{|c|}{$\begin{array}{l}\text { Dependent Variable: } Y \\
\text { Method: Least Squares } \\
\text { Date: 01/31/20 Time: } 14: 59 \\
\text { Sample: } 110 \\
\text { Included observations: } 10\end{array}$} \\
\hline Variable & Coefficient & Std. Error & t-Statistic & Prob. \\
\hline G & 671.7810 & 412.3287 & 1.629237 & 0.1419 \\
\hline $\mathrm{C}$ & -10.23347 & 26.54390 & -0.385530 & 0.7099 \\
\hline R-squared & 0.249137 & \multicolumn{2}{|c|}{ Mean dependent var } & 32.86800 \\
\hline Adjusted R-squared & 0.155280 & \multicolumn{2}{|c|}{ S.D. dependent var } & 7.468071 \\
\hline S.E. of regression & 6.863805 & \multicolumn{2}{|c|}{ Akaike info criterion } & 6.867257 \\
\hline Sum squared resid & 376.8946 & \multicolumn{2}{|c|}{ Schwarz criterion } & 6.927775 \\
\hline Log likelihood & -32.33629 & \multicolumn{2}{|l|}{ F-statistic } & 2.654412 \\
\hline Durbin-Watson stat & 1.772376 & \multicolumn{2}{|c|}{ Prob(F-statistic) } & 0.141911 \\
\hline
\end{tabular}

Hence, $\mathrm{Y}=671.7 * \mathrm{~g}-10.2, \mathrm{R}^{2}=0.24, \mathrm{SER}=6.8$

Within the range of 10 observations (2014-2019) as described in the above scatter chart 1 , coefficient 671 , when GDP growth increases, FDT stock price will increase.

Scenario 2 - Regression model with 2 variables: analyzing impact of GDP growth (G) and Inflation (CPI) on FDT stock price $(\mathrm{Y})$ :

Running Eview gives us below results:

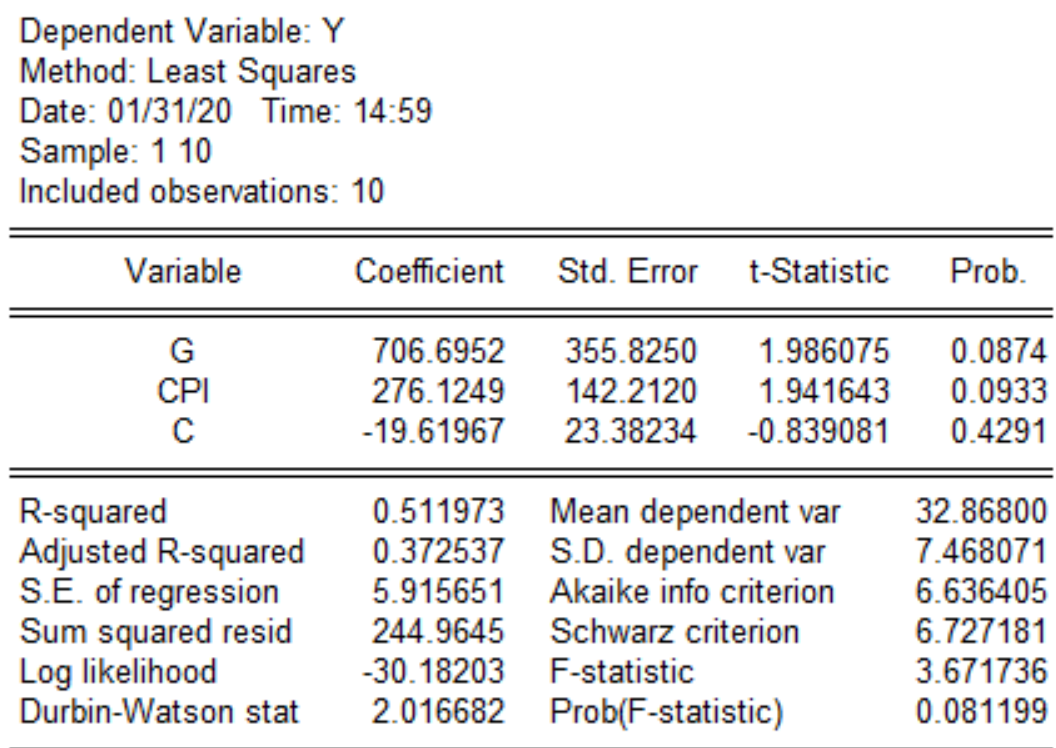

Therefore, $\mathrm{Y}=706.6 * \mathrm{~g}+276 * \mathrm{CPI}-19.6, \mathrm{R}^{2}=0.51, \mathrm{SER}=5.9$

Hence, this equation shows us FDT stock price has a positive correlation with GDP growth and inflation in Vietnam. Esp., it is highly positively affected by GDP growth rate.

Scenario 3 - Regression model with 3-5 variables: adding lending rate ${ }^{\circledR}$ and other factors into the above model 
Table 4

\begin{tabular}{|l|c|c|c|}
\hline & \multicolumn{3}{|c|}{ Co efficient } \\
\hline & 3 variables & 4 variables & 5 variables \\
\hline GDP growth & 590 & 202 & 186 \\
\hline CPI & 248 & 212 & 208 \\
\hline Lending rate & -210 & -124 & -124 \\
\hline Risk free rate & & & -48 \\
\hline VNIndex & & 0.02 & 0.01 \\
\hline C & 9.3 & 10.9 & 16.1 \\
\hline
\end{tabular}

Scenario 4 - regression model with 6 macro variables:

Running Eviews gives us results:

\begin{tabular}{|c|c|c|c|c|}
\hline \multicolumn{5}{|c|}{$\begin{array}{l}\text { Dependent Variable: } Y \\
\text { Method: Least Squares } \\
\text { Date: } 01 / 31 / 20 \text { Time: } 15: 02 \\
\text { Sample: } 110 \\
\text { Included observations: } 10\end{array}$} \\
\hline Variable & Coefficient & Std. Error & t-Statistic & Prob. \\
\hline G & 39.22084 & 408.5260 & 0.096006 & 0.9296 \\
\hline $\mathrm{CPI}$ & 196.7269 & 123.3612 & 1.594722 & 0.2090 \\
\hline $\mathrm{R}$ & -310.9357 & 261.0356 & -1.191162 & 0.3192 \\
\hline VNINDEX & -0.005274 & 0.018667 & -0.282504 & 0.7959 \\
\hline RF & -33.43907 & 150.2531 & -0.222552 & 0.8382 \\
\hline EX_RATE & 0.009014 & 0.004544 & 1.983552 & 0.1416 \\
\hline${ }^{-} \mathrm{C}$ & -142.2210 & 89.82019 & -1.583397 & 0.2115 \\
\hline R-squared & 0.860054 & \multicolumn{2}{|c|}{ Mean dependent var } & 32.86800 \\
\hline Adjusted R-squared & 0.580163 & \multicolumn{2}{|c|}{ S.D. dependent var } & 7.468071 \\
\hline S.E. of regression & 4.838925 & \multicolumn{2}{|c|}{ Akaike info criterion } & 6.187290 \\
\hline Sum squared resid & 70.24560 & \multicolumn{2}{|c|}{ Schwarz criterion } & 6.399099 \\
\hline Log likelihood & -23.93645 & \multicolumn{2}{|l|}{ F-statistic } & 3.072813 \\
\hline Durbin-Watson stat & 2.866953 & \multicolumn{2}{|c|}{ Prob(F-statistic) } & 0.192501 \\
\hline
\end{tabular}

$\mathrm{Y}=39.2 * \mathrm{G}+196.7 * \mathrm{CPI}-310 * \mathrm{R}-0.005 * \mathrm{VNINDEX}-33.4 * \mathrm{Rf}+0.009 * \mathrm{EX} \_\mathrm{RATE}-142.2$,

$$
\mathrm{R}^{2}=0.86, \mathrm{SER}=4.8
$$

Therefore, we see impacts of 6 macro factors, with the new variable: exchange rate USD/VND (EX_RATE), the above equation shows that FDT stock price (Y) has negative correlation with lending rate, VN Index and risk free rate, whereas it has positive correlation with GDP growth, CPI and exchange rate. We also recognize that GDP growth and lending rate, then CPI and risk free rate have the highest impact on FDT stock price, while exchange rate just has a slightly impact on stock price.

\section{DISCUSSION AND FURTHER RESEARCHES}

Through the regression equation with above 6 macroeconomic variables, this research paper used updated data from 20142019 to analyze the regression equation via Eview in order to show that an increase in CPI and GDP growth has a significant impact on increasing FDT stock price (Y) with the highest coefficient of impact, followed by a decrease in lending rate and decrease in risk free rate, then a decrease in VNINDEX, as well as a little increase in exchange rate. 
Data are from observations in the past 10 years, it is partly based on the market economic rules, and the research results are also affected by socio-economic characteristics in Vietnam such as: efficiency of public investment, waste of public investment, enterprise bankruptcy, and investment in areas that increase GDP such as production, electricity, etc. or investing in healthcare, environment and education sectors. We have not yet considered the impact of these factors.

Beside, we can analyze impact of another macro factor, for example, deposit rate when we add this variable into our regression model of stock price. Furthermore, we can add unemployment rate or public debt increase into our econometric model to measure the impact of these extra factors on FDT stock price.

\section{CONCLUSIONS AND POLICY SUGGESTION}

Based on the above data analysis from our regression model, although low inflation during 2015-2016 is a good signal for FDT stock price, we would suggest the government, Ministry of Finance and State Bank of Vietnam consider to control inflation more rationally, i.e not increasing much and suitable with each economic development stage. Governmental bodies and bank system also need to apply macro policies to stimulate economic growth, however not reducing lending rate too much, together with credit, operational and market risk management, corporate governance and controlling bad debt.

Next, it is necessary to coordinate synchronously between the management and administration of commercial bank policies with fiscal policies, monetary policies (used as effective tools to stimulate bank stock price) and other economic development policies to limit the negative effects of lending rate, risk free rate and exchange rate, i.e not increasing much.

Generally speaking, managing FDT stock price depends on many factors, so the government need to use fiscal policy combined with monetary policies and socio-economic policies to reduce unemployment and stimulate economic growth, toward a good stock price management.

Finally, this research paper also helps to direct further future researches, for instance, we could add deposit rate and unemployment rate into our above econometric model to measure impacts of them on stock price.

\section{ACKNOWLEDGEMENTS}

I would like to take this opportunity to express my warm thanks to Board of Editors and my family, my colleagues, and brother in assisting convenient conditions for my research paper.

\section{REFERENCES}

1. Ahmad, N., \& Ramzan, M. (2016). Stock Market Volatility and Macroeconomic Factor Volatility, International Journal of Research in Business Studies and Management, 3(7), 37-44.

2. Arshad, Z., Ali, R. A., Yousaf, S., \& Jamil, S. (2015). Determinants of Share Prices of listed Commercial Banks in Pakistan, IOSR Journal of Economics and Finance, 6(2), 56-64.

3. Ayub, A., \& Masih, M. (2013). Interest Rate, Exchange Rate, and Stock Prices of Islamic Banks: A Panel Data Analysis, MPRA Paper No. 58871.

4. Cherif, R., \& Hasanov, F. (2012). Public Debt Dynamics: The Effects of Austerity, Inflation, and Growth Shocks, IMF Working paper WP/12/230. 
5. Krishna, R.C. (2015). Macroeconomic Variables impact on Stock Prices in a BRIC Stock Markets: An Empirical Analysis, Journal of Stock \& Forex Trading, 4(2).

6. Kulathunga, K. (2015). Macroeconomic Factors and Stock Market Development: With Special Reference to Colombo Stock Exchange, International Journal of Scientific and Research Publications, 5(8), 1-7.

7. Ihsan, H., Ahmad, E., Muhamad, I.H., \& Sadia, H. (2015). International Journal of Scientific and Research Publications, 5(8)

8. Jarrah, M., \& Salim, N. (2016). The Impact of Macroeconomic Factors on Saudi Stock Market (Tadawul) Prices, Int'l Conf. on Advances in Big Data Analytics.

9. Luthra, M., \& Mahajan, S. (2014). Impact of Macro factors on BSE Bankex, International Journal of Current Research and Academic Review, 2(2), 179-186.

10. Ndlovu, M., Faisal, F., Nil, G.R., \& Tursoy, T. (2018).The Impact of Macroeconomic Variables on Stock Returns: A Case of the Johannesburg Stock Exchange, Romanian Statistical Review, 2, 88-104.

11. Pan, Q., \& Pan, M. (2014). The Impact of Macro Factors on the Profitability of China's Commercial Banks in the Decade after WTO Accession, Open Journal of Social Sciences, 2, 64-69.

12. Quy, V.T., \& Loi, D.T.N. (2016). Macroeconomic factors and Stock Price - A Case Of Real Estate Stocks on Ho Chi Minh Stock Exchange, Journal of Science Ho Chi Minh City Open University, 2(18), 63-75.

13. Saeed, S., \& Akhter, N. (2012). Impact of Macroeconomic Factors on Banking Index in Pakistan, Interdisciplinary Journal of Contemporary Research in Business, 4(6), 1200-1218.

14. https://www.sbv.gov.vn

15. https://nif.mof.gov.vn

16. Al-Ethary, Adnan Dawood M., Myieh Shbeeb Al-Shamri, and Sadek Ali Taan Al-Jobory. "The Impact of economic openness degree on GDP growth in Malaysia and some neighboring countries for the period 1990-2010." International Journal of Business and General Management (IJBGM) 3.2 (2014):57- 74.

17. Khan, Ruby. "Economic Growth Stimulation Under VAT or GST Regime; Case Study of Saudi Arabia and India." International Journal of Economics, Commerce and Research (IJECR) 10.2 (2020): 17-28.

18. Buche, Anish. "Factors Affecting Volatility in Indian Stock Markets." International Journal of Financial Management (IJFM) $5.3(2016): 1-8$.

19. Das, Saugat, and Ankit Agarwal. "Optimal Portfolio Construction of Pharmaceutical Companies-A Study on Cnx Pharma Index." International Journal of Accounting and Financial Management Research (IJAFMR) 4.3 (2014): 1-4. 


\section{EXHIBIT}
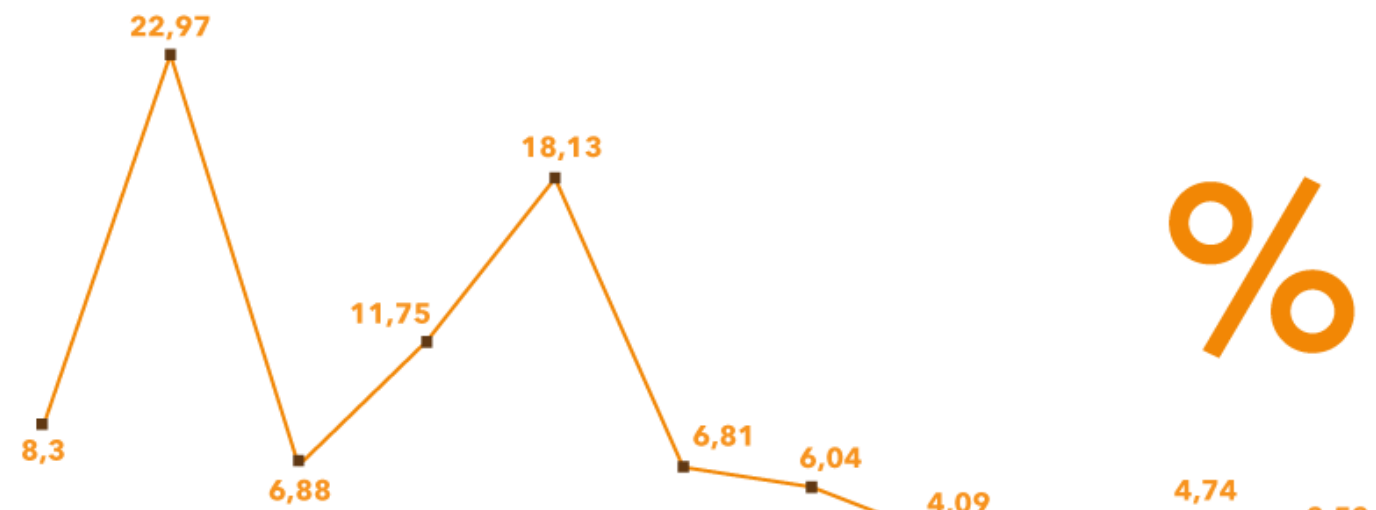

Exhibit 1: Inflation, CPI Over Past 10 Years (2007-2017) in Vietnam.

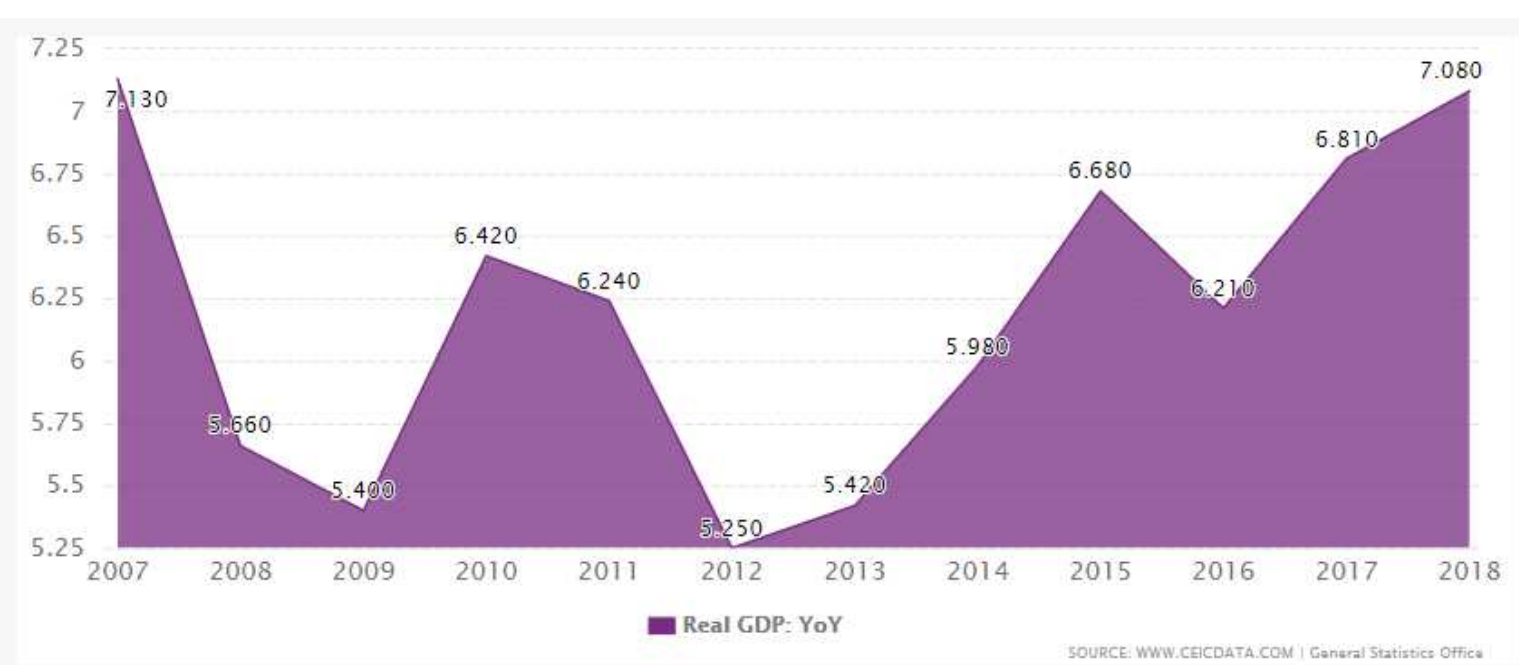

Exhibit 2: GDP Growth Rate Past 10 Years (2007-2018) in Vietnam. 